\title{
Income Poverty and Well-Being among Vulnerable Households: A Study in Malaysia
}

\author{
Nor Fairani Ahmad ${ }^{1}$, Mariani Mansor ${ }^{1} \&$ Laily Paim $^{2}$ \\ ${ }^{1}$ Department of Human Development and Family Studies, Faculty of Human Ecology, Universiti Putra Malaysia, \\ Selangor, Malaysia \\ ${ }^{2}$ Department of Resource Management and Consumer Studies, Faculty of Human Ecology, Universiti Putra \\ Malaysia, Selangor, Malaysia \\ Correspondence: Nor Fairani Ahmad, Department of Human Development and Family Studies, Faculty of \\ Human Ecology, Universiti Putra Malaysia, Selangor, Malaysia. E-mail: nor_fairani@upm.edu.my
}

Received: December 14, 2015 Accepted: December 24, 2015 Online Published: January 15, 2016

doi:10.5539/ass.v12n2p195 URL: http://dx.doi.org/10.5539/ass.v12n2p195

\begin{abstract}
The paper aims to examine the income poverty status and compare it with the well-being level between different groups among vulnerable households. Vulnerable households for this study were households that consists at least one of the following criteria: income poor, elderly person, single mothers and/or disabled person. Data was taken from the Official Poverty Line Survey conducted in four Malaysian cities representing each region in Peninsular Malaysia. A total of 286 households were conveniently selected. Descriptive statistics such as mean, standard deviation, ANOVA, correlation tests were applied in data analysis. Findings indicated significant differences in household percapita income (HHPCI) among income poverty status groups and significant differences in well-being among different status of income poverty, whereby the non-poor had the highest mean in both (HHPCI \& well-being). Also the mean well-being for poor and potential poor groups were much lower than the hardcore poor group. Further results revealed a positive but small relationship between household percapita income and well-being among vulnerable households. Finally, the findings indicated significant differences between income poor status groups and different level in well-being poor groups. It was possible for people to get out of income poverty while remaining in well-being deprivation (ill-being). Findings from this study provide evidences and enhance understanding in income poverty, well-being and correlates of both especially among vulnerable households.
\end{abstract}

Keywords: well-being, income poverty, vulnerable households, elderly person, single mothers, disabled person

\section{Introduction}

Poverty is an unacceptable human condition and one of the biggest social problems in the twentieth century. It will remain a global problem of huge population - a problem of not having enough resources and abilities to meet human basic needs both as individual and social beings due to its dynamic and multidimensional nature. At the same time, well-being, its' impact on quality of life and relationship with poverty have received substantial attention over the last decades. Both poverty and well-being are interconnected (Laily, 1995).

The incidence of poverty in Malaysia has been reduced, from $52.4 \%$ in 1970 to $1.7 \%$ in 2012 and the incidence of hardcore poverty was $6.9 \%$ in 1984, then reduced to $0.2 \%$ in 2012 (EPU Malaysia, 2012, 2010). It was a reduction of about 50.7 per cent in 42 years for incidence of poverty. Even though it showed a continuous reduction, many problems and challenges still exist, new forms of poverty have occurred and inequalities continue to rise. This is because the main challenge in tackling poverty is to cope with changing dimensions of poverty, from absolute and rural poverty to relative and urban poverty; from unidimensional to multidimensional (Wagle, 2008; Nair, 2003). These constant changes due to the process of economic transformation have resulted in social impacts and increased level of poverty for vulnerable or disadvantage groups (Zulkarnain \& Ali, 2013; Nair, 2003); added with the traditional method that does not deal with human diversity, such as, the variation of personal features of individuals (e.g. disability, critical illnesses, etc) and the differences in the socio-economic environment of each individual (e.g. single mother, elderly, etc) (Fusco, 2003). 


\subsection{Poverty Measurements}

Up until now, various approaches have been used to study and understand poverty. For long, poverty has been thought as a condition that may be wholly described in terms of income (Van Praag \& Ferrer-i-Carbonel, 2006; Lee, 2003) or consumption (Lee, 2003; Anand \& Morduch, 1996, p. 4; Laily, 1995); material ownership, household durables (Haughton \& Khandker, 2009; Vyas \& Kumaranyake, 2006), economic well-being as indicators to understand and measure poverty as well as well-being (Wagle, 2005, 2002; Van Praag \& Ferrer-i-Carbonel, 2006); as a function of lacking in individual capabilities including education, health, nutrition, gender equality, and self-respect (Wagle, 2002; Sen, 1999, 1987). While these different methods will certainly identify different groups as being poor, the ultimate aim is to design and implement specific programmes and projects targeting at helping people escape poverty and at the same time satisfied with their life as well.

In 1990 World Development Report, poverty is defined as the ability to attain a minimal standard of living, measured in terms of basic consumption needs or income required to satisfy them through a poverty line that is based on the expenditure necessary to buy a minimum standard of nutrition and other necessities (Hamdok, 1999). If household income falls below a specific income level ymin, which is called the poverty line, then the household is called poor (Van Praag \& Ferrer-i-Cabonell, 2006). According to Rojas (2008), a household is in income poverty if their household income is beneath a pre-determined income line.

Poverty in Malaysia has always been income poverty and measured using a poverty line income (PLI) to differentiate between poor and non-poor households. This poverty line is determined in absolute terms whereby an absolute poverty line is calculated in terms of the income needed to purchase a minimum requirement of a household for major components, that is food, clothing and footwear, and other non-food items such as rent, fuel and power; furniture and household equipment; medical care and health expenses; transport and communications; and recreation, education and cultural services (Mat Zin, 2011; EPU-UNDP Malaysia, 2007). By using this method, poor people are those earning an income below the PLI, whilst those earning less than half the PLI are categorized as hardcore poor.

\subsection{Well-Being Measurements}

World Bank (2001) defined poverty as the pronounced deprivation of well-being and is based on the household's level of well-being due to interconnection between poverty and well-being (Kakwani, 2006; Laily, 1995) and is seen as the lowest level of well-being (Kakwani, 2006). Researchers like Laily (1995) and Rojas (2004) view well-being as a human activities that signify a state of life condition one has attained and experienced; a concept that refers to any assessment in evaluating a person's life situation or 'being', hence, a description of individuals' life situation (McGillivray, 2007) and many social scientists highlight the need for subjectivity as foundation for a well-balanced view of human well-being, happiness, life satisfaction or subjective well-being (Tiliouine, 2007). These terms are often used interchangeably.

With an increase in income, a great number of needs are satisfied and a higher standard of well-being is achieved. Therefore, it is commonly accepted, a poor person is one whose well-being is low (Rojas, 2008). Studies in psychology have found a positive correlation between economic well-being/income and subjective well-being (Diener et al., 1993; Diener \& Biswas-Diener, 2002). However, later study by several researchers (Rojas, 2008; Fuentes \& Rojas, 2001, p.2) found that this positive relationship is weak. This is because people view their satisfaction not only by their own standard of living but also on how far better they are than their society (Fafchamps \& Shilpi, 2008) or with themselves in the past (Kingdon \& Knight, 2006). However, the correlation is much stronger for person in the lower income brackets then for those with higher incomes (Christoph, 2010).

Studies conducted on well-being in explaining poverty, found that a low income level does not necessarily indicated lack of well-being (ill-being), nor did high income levels necessarily indicated high well-being (non-ill-being) levels (Rojas, 2008). Rojas (2008) carried out a study in Mexico, found that $11.5 \%$ were income poor while being non-poor in experience poverty (life satisfaction assessment). Also, $11.2 \%$ were non income poor, while being poor in experience poverty. A study by Knight and her colleagues (2009) in rural China to examine the relationships between income poverty and well-being poverty, found that $16 \%$ of the income-poor were also well-being poor but $84 \%$ were not. Likewise, it was also possible to be unhappy despite having high income. The same study showed that $35 \%$ of the well-being-poor were also income-poor but $65 \%$ was not. Trung and his colleagues (2013) investigated ten Asian nations (Japan, South Korea, India, China, Taiwan, Thailand, Indonesia, Vietnam, Hong Kong \& Malaysia) found that regions like Malaysia, Thailand and Hong Kong were low in happiness or satisfaction even their income was high. 


\subsection{Vulnerable Households}

This study focus on those disadvantage groups as they are the most vulnerable and easily affected by the changes in income and other economic resources. Vulnerable person are those lacking the knowledge, abilities and/or resources to deal with disadvantages (e.g. physical, emotional and/or economic) or risks (Grundy, 2006). It also refers to those individuals who are at high risks of being poor. These people are unable to work and lack of income (Fengchun, 2006); who is poor in wealth, low in living standard and weak in endurance capability of the social resources distribution (Cheng, 2000, p. 21). Therefore, vulnerable households in this study are households that have at least one of the following criteria: income poor, elderly person, single mothers and/or disabled person.

The elderly person are one of the groups seen to be largely vulnerable to poverty especially those who are no longer in the workforce and having health problems. A poverty study among the elderly in low income African countries, found that the elderly only, elderly with children, and the elderly-headed households are poorer than others in eleven out of 15 sample countries (Kakwani \& Subbarao, 2007). According to Diener and Tov (2012), factors such as disabilities, the death of a spouse and being laid off from one's job, contribute to lowering people's life satisfaction, hence well-being and increase the risk of getting poor. A research of disabled people in Canada by Uppal (2006) highlighted that happiness or well-being is negatively related to the severity of disability and per capita family income has no effect on happiness (well-being). Studies conducted by Rosano, Mancini and Solipaca (2009) in Italy among people with disabilities, revealed that the disabled person need an income twice the income of the able-bodied person to enjoy the same level of economic satisfaction, as highlighted by Townsend (1979) that the disabled people often need a higher income than the non-disabled to secure comparable living standards. Another study by Schyns (2002) in 42 countries showed that people were less satisfied if they were widowed and most dissatisfied if they were divorced and another study found that divorced and widowed people were much less happy (Knight et al., 2009).

Thus, this paper discusses the results of a survey conducted in Peninsular Malaysia to identify the status of income poverty among the vulnerable household and compare it with the well-being level between different groups of income poverty status.

\section{Methods}

\subsection{The Survey}

Data was taken from an Official Poverty Line Survey (OPLS) funded by the Fundamental Research Grant Scheme (FRGS) with its' main objective to study the existing poverty measurement and make recommendations for improvement. It was conducted in four Malaysian cities representing each region (Central, North, South and East) in Peninsular Malaysia. The multistage random sampling technique was used for the areas selection at regional, state, district and sub district level. The samples were conveniently selected. A set of questionnaire was used in collecting the data that consists of several sections which included the head of household and the family's profile, social and economic background, socio-economic status perception and well-being. Upon data cleaning, exploratory data analysis (EDA) and testing on multivariate assumptions, a total of 520 samples were retained.

For the purpose of this study, only 286 respondents were analysed. Sample selection was based on the household that had at least one of the following criteria: income poor, elderly person, single mothers and/or disabled person.

\subsection{The Measures}

\subsubsection{Income Poverty (IP)}

Income poverty (IP) status was determined by using the absolute poverty measurement, the poverty line percapita income. Household percapita income was calculated by dividing the total household income with household size. It was a continuous variable and measured in Ringgit Malaysia (MYR). For Malaysia, the poverty line per capita income in 2004 based on the 2005 methodology was MYR155=USD36.50 (USD1=MYR4.25) and the hardcore poor was MYR93=USD21.90 (EPU Malaysia, 2007) and when adjusted to the 2008 consumer price index the poverty line per capita income was MYR178=USD41.92 and for the hardcore poor was MYR107=USD25.20 (EPU Malaysia, 2012). Year 2008 was taken due to the data collection was carried out in that year. The potential poor were determined by adding both figures for hardcore poor and poor which was RM285=USD67.06.

\subsubsection{Well-Being (WB)}

Well-being (WB) was measured by a 16-items question asking about one's life satisfaction as a whole and with 
respect to various domains of life, such as household income, health status, financial situation, social interaction, etc (Van Praag, Frijters \& Ferrer-i-Carbonell, 2003; Cummins, 1996) and adapted to the Malaysian context. These questions were measured on a scale of 1 (completely dissatisfied) to 10 (completely satisfied). The questions asked were: 'On a scale of 1 to 10, how satisfied are you with the following areas in your life now?'. A higher score would mean a greater level of well-being. The alpha reliability for the well-being scale items was 0.895. The respondents' mean composite score calculated for overall well-being is a continuous variable.

\subsubsection{Demographic Characteristics}

The socio-demographic variables were strata (rural=0, urban=1), gender (male=1, female $=2$ ), age, ethnic (Malay=1, Chinese $=2$, Indian=3, others $=4$ ), marital status (married $=1$, divorced $/$ widow $=2$ ), education (no formal $=0$, primary $=1$, secondary and above $=2$ ), employment status (active in employment $=1$, active self-employed $=2$, out of employment $=3$ ) and household percapita income (HHPCI) that was calculated by dividing the total household income with household size.

Of the 286 respondents, $67.1 \%$ were from rural households and $32.9 \%$ were from urban households, whilst majority (72.4\%) of these households were male-headed household and $27.6 \%$ were female-headed household. The mean age for the head of household $(\mathrm{HH})$ was 57.4 years. A significant proportion $(78.7 \%)$ for ethnic composition was Malay, followed by Indian (11.2\%), Chinese (9.4\%) and others (0.7\%). As for marital status, $71.4 \%$ were married, $28.3 \%$ were widow/divorced and only $0.4 \%$ was single. Most of these HH had education either primary $(44.7 \%)$ or secondary and above $(41.5 \%)$, only $13.8 \%$ had no formal education. The employment status composition for the $\mathrm{HH}$ was $35.3 \%$ still in employment, $25.9 \%$ were self-employed and $38.8 \%$ were unemployment. Mean household income and percapita income were MYR838.09=USD197.20 and MYR223.24=USD52.53 respectively.

\subsection{Statistical Analyses}

Data analysis was carried out using the SPSS version 21.0 program. Descriptive statistics such as frequencies, percentage, mean and standard deviation were used to identify the distribution of respondents in term of their socio-economic factors. To examine the group differences between variables, Analysis of Variance (ANOVA) test analyses were used. Chi-Square and Pearson product moment correlation were applied to predict the relationship between independent and dependent variables.

\section{Results and Discussions}

\subsection{The Distribution of the Income Poverty (IP) Status}

The highest proportion for the IP was poor (36.4\%), followed by hardcore poor $(26.9 \%)$, potential poor (15.0\%) and non-poor $(21.7 \%)$ households. Findings in Table 1 , indicated that there were statistically significant differences in household percapita income (HHPCI) among income poverty (IP) status groups ( $\mathrm{F}=195.90$, $\mathrm{p} \leq 0.05)$. The results also revealed that non-poor household had the highest HHPCI $(\mathrm{M}=545.39)$, followed by potential poor $(\mathrm{M}=216.29)$, poor $(\mathrm{M}=144.92)$ and hardcore poor $(\mathrm{M}=73.50)$. The mean HHPCI for poor and hardcore poor were obviously lower than the Malaysia poverty line (EPU Malaysia, 2012, 2007).

Table 1. Sample distribution for the income poverty status (USD1 = MYR4.25)

\begin{tabular}{ccccc}
\hline IP Status & Freq (n/\%) & Mean HHPCI (MYR) & Std. Deviation & F-Test \\
\hline Hardcore Poor (HP) & $77 / 26.9$ & 73.50 & 28.42 & F-stat=195.90 \\
Poor (P) & $104 / 36.4$ & 144.92 & 19.45 & $\mathrm{p}=0.0001$ \\
Potential Poor (PP) & $43 / 15.0$ & 216.29 & 29.13 & $\mathrm{DF}=3$ \\
Non Poor (NP) & $62 / 21.7$ & 545.39 & 258.85 & \\
\hline
\end{tabular}

\subsection{Income Poverty (IP) Status and Well-Being (WB)}

Non-poor households $(\mathrm{M}=7.16)$ had the highest level of well-being, followed by hardcore poor $(\mathrm{M}=6.45)$, then potential poor $(\mathrm{M}=6.33)$ and finally poor $(\mathrm{M}=6.26)$ households as shown in Figure 1. The comparison of mean scores of well-being $(\mathrm{F}=6.217, \mathrm{p} \leq 0.05)$ was found to be statistically significant among IP status groups.

This finding concurred with past research by Trung et al. (2012) whereby people who earned higher income did not get higher happiness and some believed that a relative increase of income compared to the lowest group will lead them to lower life satisfaction. These explained why the poor and the potential poor households had lower 
mean in WB as compared to hardcore poor households. In addition, it was easy to be happy despite having low income and possible to be unhappy despite having high income (Knight et al., 2009).

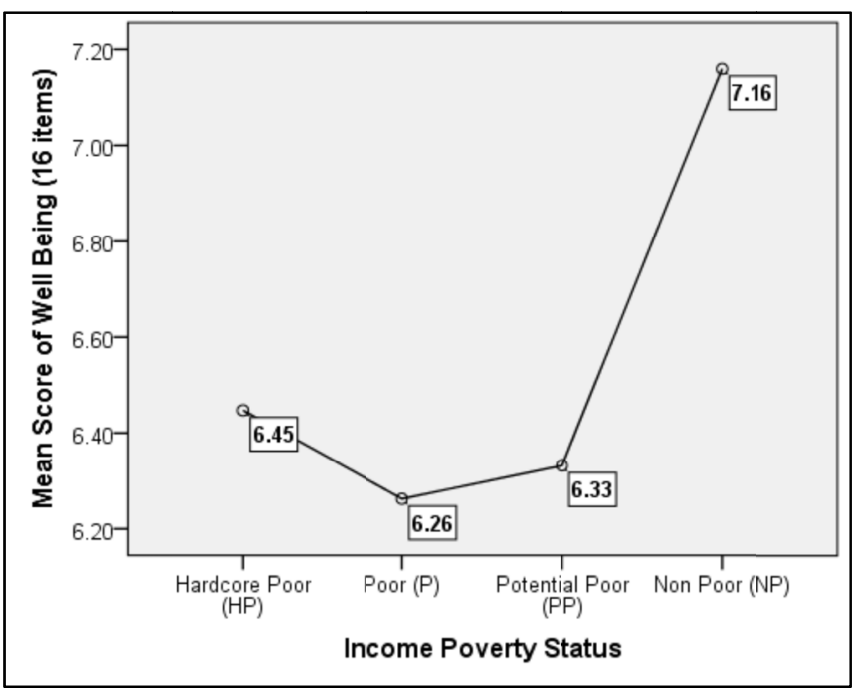

Figure 1. The mean score of WB by IP status

\subsection{The Distribution of the Well Being Poverty (WBP) Status}

As for well-being poverty (WBP), the status was determined by using the mean and \pm 1 SD average score of the well-being score. The mean was $\mathrm{M}=6.58$ and $\mathrm{SD}=1.34$. Table 2 showed the range for each status of absolute WBP.

The distribution of the WBP status was shown in Table 3. The highest proportion was ill-being (37.1\%), followed by potential ill-being (32.2\%), whilst hardcore ill-being and non-ill-being had same proportion (15.4\%). Findings on one-way ANOVA indicated that there were statistically significant differences in household WB score among absolute WBP status groups $(\mathrm{F}=689.34, \mathrm{p} \leq 0.05)$.

Table 2. Range for well-being poverty status

\begin{tabular}{cc}
\hline WBP Status & Mean Range \\
\hline $1=$ Hardcore Ill-Being (HIB) & $\leq 5.240$ \\
2 = Ill-Being (IB) & $5.241-6.580$ \\
$3=$ Potential Ill-Being (PIB) & $6.581-7.920$ \\
$4=$ Non-Ill-Being (NIB) & $\geq 7.921$ \\
\hline
\end{tabular}

Table 3. Sample distribution for the well-being poverty status

\begin{tabular}{ccccc}
\hline WBP Status & Freq (n/\%) & Mean WB & Std. Deviation & F-Test \\
\hline Hardcore Ill-Being (HIB) & $44 / 15.4$ & 4.24 & 0.86 & F-stat=689.38 \\
Ill-Being (IB) & $106 / 37.1$ & 6.03 & 0.34 & $\mathrm{p}=0.0001$ \\
Potential Ill-Being (PIB) & $92 / 32.2$ & 7.12 & 0.36 & DF=3 \\
Non-Ill-Being (NIB) & $44 / 15.4$ & 8.61 & 0.50 & \\
\hline
\end{tabular}

\subsection{Correlate of Household Per Capita Income (HHPCI) and Well-Being (WB)}

Table 4 showed the correlation matrix between household percapita income (HHPCI) and well-being (WB). Result indicated that the correlation was statistically significant at 0.01 level of significance with positive relationship. However, the relationship between both variables was small. This was in accordance with the previous findings by Fuentes and Rojas (2001), Diener and Biswas-Diener (2002) and Diener et al. (1993). 
Table 4. Correlation between HHPCI and WB

\begin{tabular}{|c|c|c|c|}
\hline & & WB & HHPCI \\
\hline \multirow{3}{*}{ Well-being (WB) } & Pearson Correlation & 1.000 & $0.219 * *$ \\
\hline & Sig (2-tailed) & & 0.000 \\
\hline & $\mathrm{N}$ & 286 & 286 \\
\hline \multirow{3}{*}{$\begin{array}{l}\text { Household Percapita Income } \\
\text { (HHPCI) }\end{array}$} & Pearson Correlation & $0.219 * *$ & 1.000 \\
\hline & Sig (2-tailed) & 0.000 & \\
\hline & $\mathrm{N}$ & 286 & 286 \\
\hline
\end{tabular}

\subsection{Income Poverty (IP) and Well Being Poverty (WBP) Status}

Table 5 showed the WBP status situation for every category of IP group among vulnerable households. The result of chi-square test of independence to assess whether the IP status was related to the different level of WBP among these households revealed that there were significantly related with low association [Pearson $\chi^{2}$ (9, $\mathrm{N}=286)=18.931, \mathrm{p} \leq 0.05]$.

Findings also revealed that as we moved from hardcore poor to non-poor group more vulnerable households were in ill-being and potential ill-being status. About $30 \%$ of these households who were hardcore poor perceived themselves as potential ill-being and about $12 \%$ perceived themselves as non- ill-being. As for poor vulnerable households, those who perceived themselves as potential ill-being were about 31\% and non- ill-being were $12 \%$. The total proportion of both hardcore poor and $\mathrm{P}$ who perceived themselves as potential ill-being and non- ill-being were about $27 \%$ of the total vulnerable households.

Meanwhile, about 19\% of PP households who were in hardcore ill-being and about 37\% perceived themselves as ill-being. As for non-poor households, those who perceived themselves as hardcore ill-being were only $1.6 \%$ and ill-being was $32.3 \%$. The total proportion of both potential poor and non-poor households who perceived themselves as hardcore ill-being and ill-being were about $16 \%$ of the total vulnerable households. Conclusively, there still existed hardcore poor and poor households who perceived themselves as potential ill-being and nonill-being. Vice versa, potential poor and non-poor households who perceived themselves as hardcore ill-being and ill-being.

Table 5. Distribution of absolute income poverty and absolute well-being poverty among vulnerable households

\begin{tabular}{|c|c|c|c|c|c|}
\hline \multirow[b]{2}{*}{ Income Poverty } & \multicolumn{4}{|c|}{ Well Being Poverty ( $n / \%$ within row) $\%$ of total } & \multirow[b]{2}{*}{ Total } \\
\hline & $\begin{array}{c}\text { Hardcore Ill-Being } \\
\text { (HIB) }\end{array}$ & $\begin{array}{l}\text { Ill-Being } \\
\text { (IB) }\end{array}$ & $\begin{array}{c}\text { Potential Ill-Being } \\
\text { (PIB) }\end{array}$ & $\begin{array}{c}\text { Non Ill-Being } \\
\text { (NIB) }\end{array}$ & \\
\hline \multirow{2}{*}{ Hardcore Poor (HP) } & $15 / 19.5$ & $30 / 39.0$ & $23 / 29.9$ & $9 / 11.7$ & $77 / 100$ \\
\hline & 5.2 & 10.5 & 8.0 & 3.1 & 26.9 \\
\hline \multirow{2}{*}{ Poor $(\mathrm{P})$} & $20 / 19.2$ & $40 / 38.5$ & $32 / 30.8$ & $12 / 11.5$ & $104 / 100$ \\
\hline & 7.0 & 14.0 & 11.2 & 4.2 & 36.4 \\
\hline \multirow{2}{*}{ Potential Poor (PP) } & $8 / 18.6$ & $16 / 37.2$ & $13 / 30.2$ & $6 / 14.0$ & $43 / 100$ \\
\hline & 2.8 & 5.6 & 4.5 & 2.1 & 15.0 \\
\hline \multirow{2}{*}{ Non-Poor (NP) } & $1 / 1.6$ & $20 / 32.3$ & $24 / 38.7$ & $17 / 27.4$ & $62 / 100$ \\
\hline & 0.3 & 7.0 & 8.4 & 5.9 & 21.7 \\
\hline \multirow{2}{*}{ Total } & $44 / 15.4$ & $106 / 37.1$ & $92 / 32.2$ & $44 / 15.4$ & $286 / 100$ \\
\hline & 15.4 & 37.1 & 32.2 & 15.4 & 100.0 \\
\hline
\end{tabular}

Pearson $\chi^{2}=18.931^{\mathrm{a}} \mathrm{DF}=9 \quad p$-value $=0.026 \quad$ Contingency Coef. $=0.249$

a. 0 cells $(.0 \%)$ have expected count less than 5 . The minimum expected count is 6.62 . 
These findings concurred with the past studies by Rojas (2008). According to Trung et al. (2012), Malaysian people said higher income did not increase happiness thus, made their happiness lower compared to the lowest quintile of income. As highlighted by Diener and Tov (2012) that income had a greater impact on subjective well-being in poor societies because basic needs were highly salient and the relation between income and happiness was reduced among wealthier nations (Diener et al., 1993). This could be due to greater amount of income enable the pursuit of other goals that added to one's level of well-being. Conversely, people with a comparably low income might still displayed high well-being, since despite the low financial returns they still fulfill the norm by being involved in a productive activity (Christoph, 2010).

\section{Conclusions and Implications}

This paper aims to examine the status of income poverty among the vulnerable household and compare it with the well-being status between different groups of income poverty status. Firstly, the results of this study indicate that there are statistically significant differences in household percapita income (HHPCI) among income poverty (IP) status groups. Secondly, the findings show differences in well-being among different status of income poverty groups. Results also show that mean well-being for poor and potential poor households are much lower than the hardcore poor households. Thirdly, there are statistically significant differences in household well-being score among well-being poverty (WBP) status groups.

Furthermore, the results of this study also reveal a positive relation between household percapita income (HHPCI) and well-being, however the correlation is small. It is a known fact that money may enhance well-being when it means avoiding poverty by meeting their basic needs, however income appears to increase well-being little over the long-term when more of it is gained by well-off individuals whose material desires rise with their incomes as highlighted by Diener and Biswas-Diener (2002) and Souza and Lyubormirsky (2001).

Finally, the findings indicate significant differences between IP status groups and different level in WBP groups. Also, there are still a lot of poor people according to the income poverty who view themselves as not being in well-being poverty, whilst those who well-being poor (ill-being) who are not in income poverty. Conclusively, it is possible for people to get out of income poverty while remaining in well-being deprivation (ill-being).

Income has an effect only at extreme levels of poverty, but once the basic needs are met, income is no longer influential (Rojas, 2004). Social comparison is an important aspect in understanding this phenomenon. Once certain level of wealth is achieved, life satisfaction is no longer attached to the increases in wealth and material goods. Social comparison will step in because of the changing standards of one's expectation by comparing their situation with others.

The findings from this paper would enrich our understanding of WB by examining its' relationship with income poverty. Furthermore, it provides sufficient evidences that would be useful information in formulating economic and social policies, and also in setting priorities when designing poverty eradication programs that not only target at getting people out of income poverty but also should put them in a situation that fosters their well-being especially among vulnerable households.

\section{Acknowledgements}

Sincere appreciation is extended to Universiti Putra Malaysia and Ministry of Higher Education Malaysia for their support in this research.

\section{References}

Alkire, S. (2007). Choosing Dimensions: The Capability Approach and Multidimensional Poverty. Chronic Poverty Research Centre Working Paper No. 88. http://dx.doi.org/10.2139/ssrn.1646411

Anand, S., \& Morduch, J. (1996). Poverty and the Population Problem: Evidence from Bangladesh. Harvard Institute for International Development, Development Discussion Paper No. 559. Retrieved from http://www.cid.harvard.edu/hiid/559.pdf

Cheng W. (2000). About the Disadvantaged Persons, Current Event Publishing House (p. 21). As cited in Fengchun, Y. (2006). The Status of Vulnerable Groups in the Chinese e-Government Construction. Paper presented in Capacity Building of Asia Pacific e-Government Initiatives, UNCRD and UNDP-APDIP Regional Workshop: Bangkok, 24-25 April.

Christoph, B. (2010). The Relationship between Life Satisfaction and the Material Situation: A Re-evaluation using Alternatives Measures. Social Indicators Research, 98, 475-499. http://dx.doi.org/10.1007/s11205009-9552-4

Cummins, R.A. (1996). The Domains of Life Satisfaction: An Attempt to Order Chaos. Social Indicators 
Research, 38(3), 303-328. http://dx.doi.org/10.1007/BF00292050

Diener, E., \& Biswas-Diener, R. (2002). Will money increase subjective well-being? A literature review and guide to needed research. Social Indicators Research, 57, 119-169. http://dx.doi.org/10.1023/A:10144113 19119

Diener, E., \& Tov, W. (2012). National Accounts of well-being. In K. C. Land, A. C. Michalos, \& M. J. Sirgy (Eds.), Handbook of Social Indicators and Quality of Life Research (pp. 137-157). New York, NY: Springer. http://dx.doi.org/10.1007/978-94-007-2421-1_7

Diener, E., Sandvik, E., Seidlitz, L., \& Diener, M. (1993). The Relationship Between Income and Subjective Well-Being: Relative or Absolute? Social Indicators Research, 28, 195-223. http://dx.doi.org/10.1007/BF0 1079018

EPU (Economic Planning Unit) Malaysia. (2010). Tenth Malaysia Plan, 2011-2015. Putrajaya: Prime Minister's Department.

EPU (Economic Planning Unit) Malaysia. (2012). Socio-economic Statistics: Household Income and Poverty. Retrieved November 20, 2012, from http://www.epu.gov.my/household-income-poverty

EPU-UNDP Malaysia. (2007). Malaysia: Measuring and Monitoring Poverty and Inequality. Kuala Lumpur: UNDP.

Fafchamps, M., \& Shilpi, F. (2008). Subjective welfare, isolation, and relative consumption. Journal of Development Economics, 86, 43-60. http://dx.doi.org/10.1016/j.jdeveco.2007.08.004

Fengchun, Y. (2006). The Status of Vulnerable Groups in the Chinese e-Government Construction, paper presented in Capacity Building of Asia Pacific e-Government Initiatives. UNCRD and UNDP-APDIP Regional Workshop: Bangkok, 24-25 April.

Fuentes, N., \& Rojas, M. (2001). Economic Theory and Subjective Well-Being: Mexico, Social Indicators Research. The Netherlands, Marzo: Kluwer Academic Press. Retrieved from http://link.springer.com/article/ 10.1023/A:1007189429153

Fusco, A. (2003). On the definition and measurement of poverty: The contribution of multidimensional analysis. 3rd Conference on The Capability Approach: From Sustainable Development to Sustainable Freedom. University of Pavia, 7-9 September.

Grundy E. (2006). Ageing and Vulnerable Elderly People: European Perspectives. Ageing \& Society, 26, 105-134. http://dx.doi.org/10.1017/S0144686X05004484

Hamdok, A. A. (1999). A Poverty Assessment Exercise in Zimbabwe. USA: African Development Bank.

Haughton, J., \& Khandker, S. R. (2009). Handbook on Poverty and Inequality. Washington DC: The World Bank. http://dx.doi.org/10.1596/978-0-8213-7613-3

Kakwani, N. (2006). Poverty and Wellbeing. A Chapter in Dag Ehrenpreis (eds). What is Poverty? Concepts and Measures. Poverty in Focus, (9). Brazil: UNDP International Poverty Centre (IPC).

Kakwani, N., \& Subbarao, K. (2007). Poverty Among the Elderly in Sub-Saharan Africa and the Role of Social Pensions. Journal of Development Studies, 43(6), 987-1008. http://dx.doi.org/10.1080/00220380701466476

Kingdon, G. G., \& Knight, J. (2006). Subjective Well-Being Poverty versus Income Poverty and Capabilities Poverty? Journal of Development Studies, 42(7), 1199-1224. http://dx.doi.org/10.1080/00220380600884 167

Knight, J., Song, L., \& Gunatilaka, R. (2009). Subjective Well-Being and its Determinants in Rural China. China Economic Review, 20(4), 635-649. http://dx.doi.org/10.1016/j.chieco.2008.09.003

Laily, P. (1995). A Consumption Model for Measuring Poverty: An Exploratory Exercise. Social Indicators Research, 35(2), 129-153. http://dx.doi.org/10.1007/BF01079024

Lee, J. W. (2003). Income, Consumption and Poverty. Social Indicators Research, 62(63), 197-209. http://dx.doi.org/10.1023/A:1022697217856

Mat Zin, R. (2011). Measuring and Monitoring Poverty and Inequality: The Malaysian experience. Singapore: Institute of Southeast Asian Studies.

McGillivray, M. (2007). Human Well-being: Concept and Measurement, UNU-WIDER. N.Y.: Palgrave Macmillan. Retrieved from http://wwww.rrojasdatabank.info/humanwellbeing.pdf 
Nair, S. (2003). Poverty in Malaysia: Trends and Changing Dimensions, a chapter in The State Economic Development and Ethnic Co-Existence in Malaysia and New Zealand. Kuala Lumpur: CEDER.

Rojas, M. (2004). Well-Being and the Complexity of Poverty: A Subjective Well-being Approach. Research Paper 2004-29. United Nations University-WIDER. Retrieved from http://hdl.handle.net/10419/63558

Rojas, M. (2008). Experienced Poverty and Income Poverty in Mexico: A Subjective Well-Being Approach. World Development. http://dx.doi.org/10.1016/j.worlddev.2007.10.005

Rosano, A., Mancini, F., \& Solipaca, A. (2009). Poverty in People with Disabilities: Indicators from the Capability Approach. Social Indicators Research, 94, 75-82. http://dx.doi.org/10.1007/s11205-008-9337-1

Schyns, P. (2002). Wealth of nations, individual income and life satisfaction in 42 countries: A multilevel approach. Social Indicators Research, 60, 5-40. http://dx.doi.org/10.1023/A:1021244511064

Sen, A. K. (1987). The Standard of Living. In G. Hawthorn (Ed.), The Standard of Living. Cambridge: Cambridge University Press.

Sen, A. K. (1999). Development as Freedom. New York: Anchor Books.

Sousa, L., \& Lyubomirsky, S. (2001). Life satisfaction. In J. Worell (Ed.), Encylopedia of women and gender: Sex similarities and differences and the impact of society on gender (Vol. 2, pp. 667-676). San Diego, CA: Academic Press. Retrieved from http://sonjalyubomirsky.com/wp-content/themes/sonjalyubomirsky/papers/ SL2001.pdf

Tiliouine, H. (2007). Health and Subjective Wellbeing in Developing Countries: The Case of Algeria. WeD Working Paper 39, ESRC Research Group on Wellbeing in Developing Countries. UK: University of Bath. Retrieved from http://www.welldev.org.uk/research/workingpaperpdf/wed39.pdf

Townsend, P. (1979). Poverty in the United Kingdom. London: Allen Lane and Penguin Books. Retrieved from http://193.104.168.102/drupal7/free-resources-books/poverty-united-kingdom

Trung, N. N., Cheong, K., Nghi, P. T., \& Kim, W. J. (2012). Relationship between Socio-Economic Values and Wellbeing: An Overview Research in Asia. Social Indicators Research, Published online: 17 March. http://dx.doi.org/10.1007/s11205-012-0014-z

Uppal, S. (2006). Impact of the timing, type and severity of disability on the subjective well-being of individuals with disabilities. Social Science \& Medicine, 63, 525-539. http://dx.doi.org/10.1016/j.socscimed.2006.01. 016

Van Praag, B. M. S., Frijters, P., \& Ferreri-Carbonell, A. (2003). The Anatomy of Subjective Well-Being. Journal of Economic Behavior \& Organization, 51, 29-49. http://dx.doi.org/10.1016/S0167-2681(02)00140-3

Van Praag, B., \& Ferrer-i-Carbonell, A. (2006). A Multidimensional Approach to Subjective Poverty. A modified version of a paper, presented at the occasion of the opening conference on 'The Measurement of Multidimensional Poverty, Theory and Evidence' of The International Poverty Centre (UNDP) in Brasilia, August 29, 2005. Retrieved from http://www.iae.csic.es/investigatorsMaterial/a71312152653archivoPdf62 069.pdf

Vyas, S., \& Kumaranayake, L. (2006). Constructing Socio-economic Status Indices: How to Use Principal Components Analysis. Health Policy Plan, 21(6), 459-468. http://dx.doi.org/10.1093/heapol/cz1029

Wagle, U. (2002). Rethinking poverty: Definition and measurement. International Social Science Journal, 54(171), 155-165. http://dx.doi.org/10.1111/1468-2451.00366

Wagle, U. (2005). Multidimensional Poverty Measurement with Economic Well-being, Capability, and Social Inclusion: A Case from Kathmandu, Nepal. Journal of Human Development, 6(3), 301-328. http://dx.doi.org/10.1080/14649880500287621

Wagle, U. (2008). Multidimensional Poverty Measurement: Concepts and Application. USA: Springer. http://dx.doi.org/10.1007/978-0-387-75875-6

World Bank. (2001). World Development Report 2000/2001: Attacking Poverty. New York: Oxford University Press, Washington D.C. Retrieved from https://openknowledge.worldbank.org/handle/10986/11856

Zulkarnain A. H., \& Ali, I. (2013). Poverty Reduction Policies in Malaysis: Trends, Strategies and Challenges. Asian Culture and History, 5(2), 48-56. http://dx.doi.org/10.5539/ach.v5n2p48 


\section{Copyrights}

Copyright for this article is retained by the author(s), with first publication rights granted to the journal.

This is an open-access article distributed under the terms and conditions of the Creative Commons Attribution license (http://creativecommons.org/licenses/by/3.0/). 